\title{
Membrane bioreactors for metal recovery from wastewater: A review
}

\author{
C Mack, JE Burgess*, JR Duncan \\ Department of Biochemistry, Microbiology and Biotechnology, Rhodes University, PO Box 94, Grahamstown 6139, South Africa
}

\begin{abstract}
The need to remove or recover metal ions from industrial wastewaters is both financially and environmentally driven, financially in terms of cost savings through metal reuse or sale, and environmentally as heavy metal toxicity can affect organisms throughout the food chain, including humans. Current removal strategies are mainly based on physico-chemical techniques such as filtration, chemical precipitation and solvent extraction. All these "conventional" technologies have raised issues of efficacy when faced with low metal concentrations, high start-up or operating costs and low metal selectivity. Conversely, metal removal using biological and membrane processes is becoming more widely accepted as new evidence is gathered highlighting their lower cost, ease of operation, selectivity and efficacy. Precipitation of metal ions using biogenic hydrogen sulphide, produced by sulphate-reducing bacteria, is not a new technique, and is used by a small number of industrial installations worldwide. While this process has disadvantages such as the hazardous nature of the gas, the advantages inherent in utilising this source of sulphide are greatly enhanced when used in combination with membrane bioreactor technology. Initial studies have shown that the sulphate-reducing bacterial bioreactor coupled with a membrane can remove up to $90 \%$ of the metal ions present in an aqueous solution.
\end{abstract}

Keywords: membrane bioreactor, metal removal, sulphate-reducing bacteria, extractive membrane bioreactor

\section{Introduction}

Water is an important resource, vital for both social and economic growth. It is thus imperative that water is managed according to the principles of sustainable development to counteract the combination of increasing economic development and environmental degradation. The constantly increasing degree of industrialisation and urbanisation, rising standards of living, increasing population growth and agricultural activities are strongly impacting on the use of available water sources and on the quality of water that is found therein. This exhaustive use of limited resources and energy by modern society implies a need for changes in present and future urban water and wastewater treatment systems (Holtzhausen, 2002).

A larger problem faces developing countries, like South Africa, that have moderate to high stresses on their freshwater resources, as large inequalities exist in the quality and quantity of water available to rural communities compared to that of the urban areas (Morrison et al., 2001). Thus, appropriate management strategies need to be implemented to optimise the use of these water sources and to ensure the efficient disposal of polluted water (Jooste, 2000).

\section{Water in South Africa}

South Africa's average annual rainfall is approximately $480 \mathrm{~mm}$ almost half the world average of $860 \mathrm{~mm}$. The fact that this rainfall is unevenly distributed across the country, much higher in the east than in the west, compounds the problem of water supply

* To whom all correspondence should be addressed.

益+2746 603 8629; fax:+2746 622 3984; e-mail: j.burgess@ru.ac.za Received 20 November 2003; accepted in revised form 2 August 2004
(Holtzhausen, 2002). To alleviate this inequality between the eastern and western areas of the country, numerous dams, storage facilities and inter-catchment transfer schemes have been developed. Thus, South Africa is heavily reliant on surface water resources and, with evaporation rates much higher in the west than in the east, the potential water shortage problem is evident (Webster, 2001).

Major industries, mining and power generators account for a large percentage of water usage in South Africa. These are found mainly in Gauteng, Mpumalanga and Limpopo Provinces, which are highly populated, due in part to the labour force required to run such industries and the resulting commercial and residential areas surrounding them. The result is a very high water demand by both industrial and domestic users in an area of generally low rainfall (Fig. 1) (Holtzhausen, 2002).

In combination with the two water-related issues of increasing urbanisation and uneven resource distribution, the need for sufficient water to sustain aquatic ecosystems and the environmental services they provide results in a requirement for a fine balance when it comes to allocating resources to users.

Schutte and Pretorius (1997) state that of the total water resource presently available, $52 \%$ is used for agricultural activities, $12.5 \%$ by industry, mining and power generation and $12 \%$ for domestic and municipal uses. Holtzhausen (2002) echoes these consumption estimates and further states that at least $15 \%$ of the water resources remaining are required for nature conservation and ecological purposes such as maintaining estuaries and rivers (Fig. 2.).

This need has been recognised in the national legislation under the National Water Act (1998) that outlines three policy principles for water resource protection strategies. These are:

- Protection of all significant water resources

- Resource sustainability, i.e. use that does not cause long-term deterioration of the overall resource in terms of any measurable 


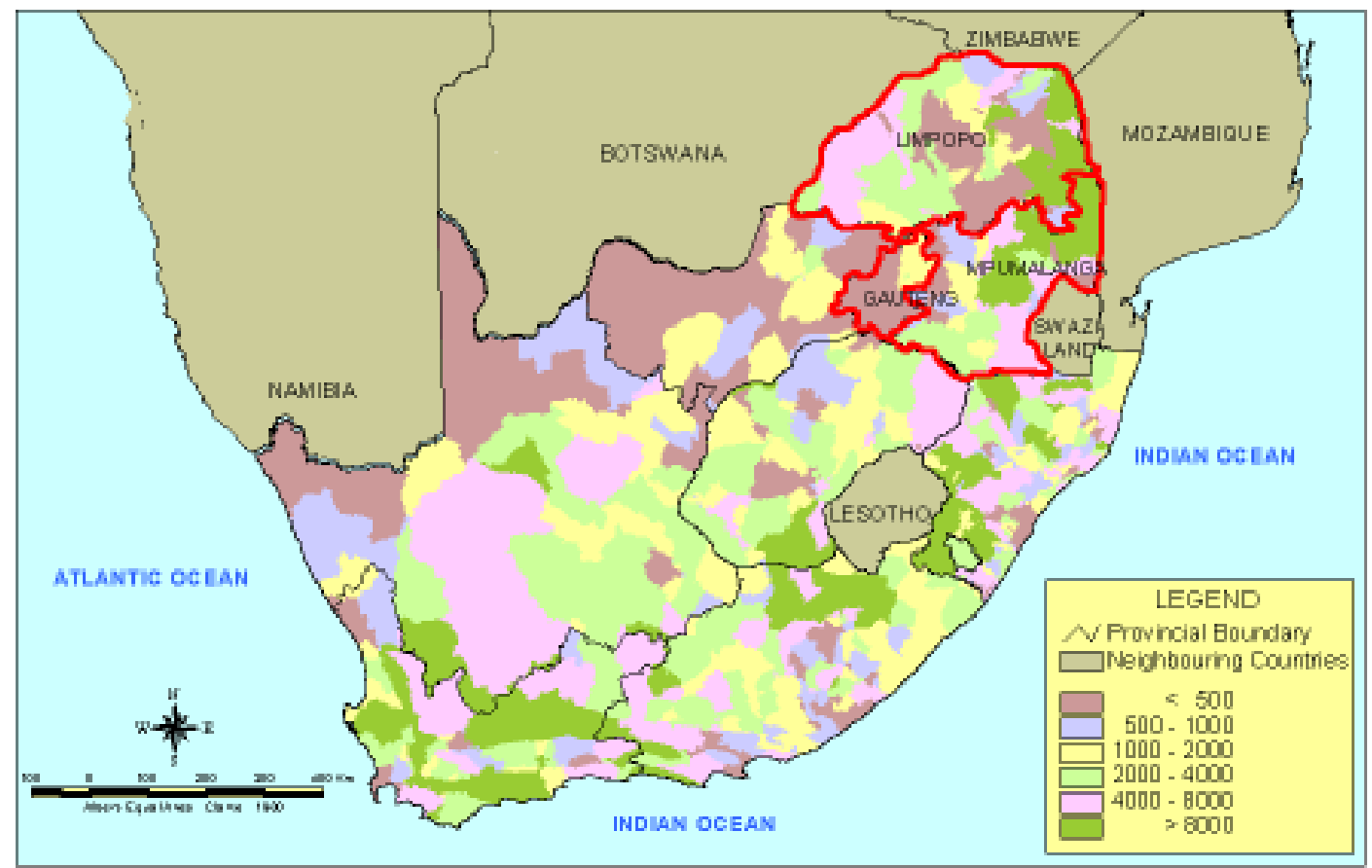

Figure 1

Availability of water per

capita in South Africa

(Department of Environmental

Affairs and

Tourism, 2001)

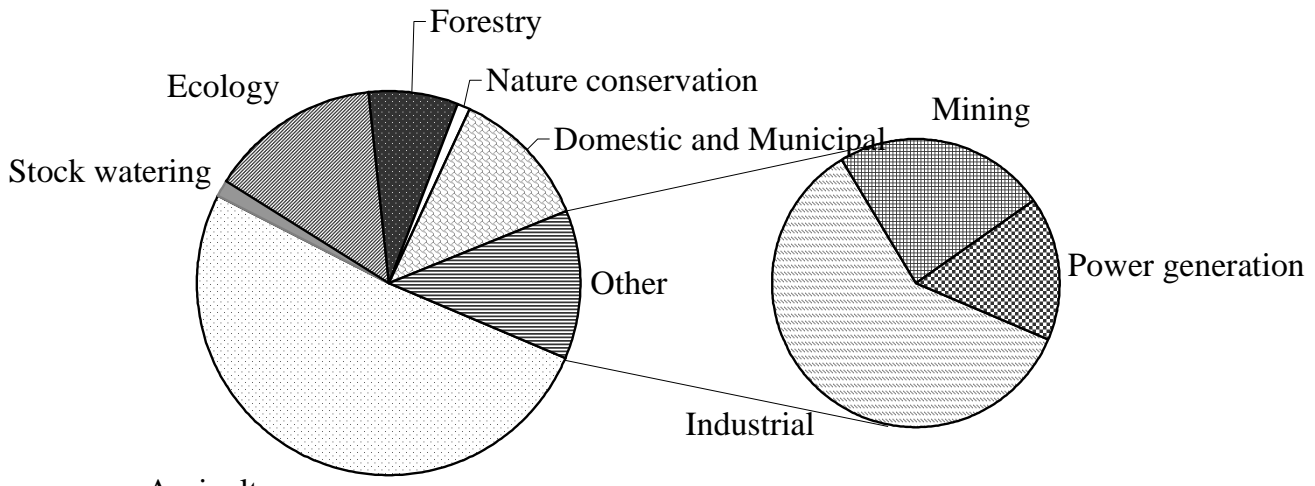

Figure 2

Current sectoral consumption of available water resources

(Holtzhausen, 2002; Schutte and Pretorius, 1997)

Agriculture

criteria (e.g. quality and quantity) (Wright and $\mathrm{Xu}, 2000$ )

- Integrated water resource management of all water user groups.

It is the $3^{\text {rd }}$ principle that places pressure on all industries to reconsider their current water management strategies and to look for ways to increase the amount of reuse and recycling that occurs within the industry.

The most widely used raw material in process industries, as well as being an abundant component of chemical, petrochemical, petroleum refining, food and drink, pulp and paper and many other industries, is water (Baetens, 2002). In light of the potentially chronic water shortages facing South Africa, awareness and motivation among the larger users for optimisation of water utilisation is increasing. This increase is as a result of powerful economic driving forces such as increased costs of wastewater treatment, higher environmental standards and the increasing scarcity and cost of good quality water sources (Alva-Argáez et al., 1998). Water use minimisation can be achieved in three basic ways:

- Reduction in the use of fresh water by instituting changes in the process (Zhelev and Bhaw, 2000; Alva-Argáez et al., 1998)

- Reuse of process water in areas where the quality of the water is not key and will not adversely affect the process into which it is being added
- Reduction in water treatment costs by implementing low-cost biological treatments and reusing this treated water (AlvaArgáez et al., 1998).

The $3^{\text {rd }}$ option can be further split into regeneration reuse and regeneration recycling. Regeneration reuse involves partial recycling to remove contaminants that may affect the process into which the water is being added. Regeneration recycling requires that the treatment remove any contaminants that may build up, as the treated water will pass through the same process from which it was taken (Zhelev and Bhaw, 2000).

South African industries are experiencing increasing international pressure to reduce the amount of freshwater used and the amount of effluent produced. A technique known as water pinch analysis is gaining in popularity as a 'cleaner production' technique and is aimed at reducing freshwater consumption and wastewater production by analyzing current and proposed industrial complexes and pinpointing areas where changes such as those mentioned earlier can be implemented(Gianadda et al., 2002; Zhelev and Bhaw, 2000). In South Africa, the Pollution Research Group from the University of KwaZulu-Natal have been at the forefront of water pinch analysis implementation by aiding diverse industries in the analysis of their own water usage and highlighting the possibilities for change (Brouckaert et al., 2002;). 
Industries involving the extraction, purification and application of metals are generally highly water-intensive. For example, in 2002, a Water Research Commission (WRC) study estimated that the electroplating industry produced approximately $1 \mathrm{~km}^{3}$ of liquid effluent per annum globally (Swalaha et al., 2002).

Effluent streams released by these industries are characterised by contaminants such as cyanides, heavy metals, associated salts, oils and greases, cleaning aids and solvents (Cowan, 1998). These contaminants arise, in one way or another, from processes within the industry and, depending on the process, the reclamation of components such as organic solvents and metals from these waste streams may be financially viable.

The major factors used to determine the financial viability of reclamation include the volume of water that contains metals, the concentrations of those metals in the water and the potential to recirculate some of the metal salts and recovered waters as opposed to paying discharge fees and penalties (Cowan, 1998).

For industries such as electroplaters and finishers, the cost involved in the treatment of the effluent produced is sometimes prohibitively expensive, especially for the smaller installations, and far outweighs the advantages of recycling and regenerating materials. Cowan (1998) suggests that a centralised waste treatment (CWT) plant be set up to provide such services to a number of small industries in a given area, which would lower capital costs and still produce the advantages inherent in the idea. For mines and metal refiners, however, the possibility of retaining every milligram of metal value is highly attractive and the increase in profit gained by the extra metal value should outweigh the cost of the treatment plant installation. Present treatment strategies require costly chemical and physical operations and involve a high degree of maintenance and operating supervision. Reliable treatment systems that are costeffective and low in maintenance would be an ideal solution for these mines and metal refiners.

\section{Classical methods of metal removal from wastewater}

The recovery of metals from wastewater has a twofold advantage. Firstly, it minimises the contamination of the aquatic environment and secondly, recovering metals of value such as gold and platinum group metals (PGMs) would have significant commercial value (Volesky, 1990). According to convention, the majority of current metal removal and recovery technologies are physical or chemical in nature. Biological systems however, are gaining in popularity as they are increasingly being proved to be as effective as physical methods while operating at substantially lower costs (Eccles, 1999). Membrane systems are still being developed and most potential applications involve the use of membranes as either filtration devices (Juang and Shiau, 2000) or as metal ion chelators in combination with other adsorbent material (Genç et al., 2003). Metal accumulation tends to be a function of the metal concentration. Where metals are in high concentrations (>500 mg/ $\ell$ ) they can be recovered by electrolysis, while at low concentrations $(<5 \mathrm{mg} / \ell)$ they can be removed by biosorption or ion exchange. At concentrations between 500 and $5 \mathrm{mg} / \ell$, precipitation with lime is possible, generating high volumes of sludge with low metal/sludge ratios (Diels et al., 1993).

\section{Metal removal methods available}

There are a number of strategies available, including cementation, solvent extraction, evaporation, ion exchange, chemical precipitation, biological treatment and membrane processing.
The application of cementation reactions in industry has attracted attention over the past century. This technology has found application in recovering silver from electro-winning and copper from electro-refining (Sulka and JaskuBa, 2003). The principle of cementation is the contact between the metal in solution and metal of a higher electronegativity series. This causes the displacement of the metal from solution (Lee et al., 1998)

Solvent extraction, or liquid ion exchange, is well established in wastewater remediation and involves extracting the metal by contacting the solution with an organic reagent that will react with the metal ion and result in its conversion to a dissolved form in the solvent. For optimal operation, this method requires high initial metal concentrations (Kentish and Stevens, 2001). However, the environmental standards for acceptable metal levels in discharged water cannot be met with this method alone. It is preferable to utilise it in conjunction with other treatment systems such as membranes (Kentish and Stevens, 2001). Solvent extraction of metals is widely employed for selective recovery. It is one of the most common methods used for the separation of PGMs from aqueous solutions due to the simplicity of the process (Gholivand and Nozari, 2000). The precious metal anions are usually extracted by ion-pair formation with long-chain alkyl amines such as tri-n-octylamine (TOA), methyl tricaprylyl ammonium chloride (Aliquot 336), methyl isobutyl ketone (MiBK) and other amines (Adams, 2003; Kentish and Stevens, 2001).

Mining operations may "treat" metal-contaminated waters using atmospheric evaporation of the water, which causes a concentrated metal-bearing sludge to be formed. The dams required for this method can occupy vast areas of land, making it a viable option only for processes where this land is available close by. Vacuum evaporation, in which the water is vaporised at lower temperatures, is only occasionally employed, as the equipment required is complex and expensive to construct and maintain (Cowan, 1998).

The use of ion-exchange results in highly successful metal recovery from pretreated waste. Conventional ion-exchange resins have been used in conjunction with solvent extraction in the recovery of metals. The ease of phase separation and high concentration efficiency of ion exchange mask the disadvantages of solvent extraction, mainly the difficulty in phase separation (Adams, 2003). However, these ion exchangers are not sufficiently selective to remove certain metals from large volumes of accompanying metals and thus metal-selective resins are being developed (Cortina et al., 1998). Unfortunately, these methods are relatively expensive, requiring elaborate equipment with high operation costs, such as the regeneration and/ or disposal of the regeneration liquid and the spent resin, and large energy requirements. Resin usage causes a large environmental burden in terms of disposal (Lee et al., 1998). Table 1 summarises the major performance characteristics of some of the physico-chemical methods used commercially.

There is however, a global trend moving towards more stringent environmental standards and legislation, the current economic climate encourages the introduction of relatively low-cost pollution treatment systems. The benefits of biological systems are becoming more apparent as a greater number are successfully implemented. These natural systems are often referred to as "green” technologies as they involve naturally occurring biological phenomena and systems. Two important phenomena, biosorption and bioaccumulation, are implicated in the removal of metal ions from wastewater in all biological systems. These can occur in both plant and microbial species. Bioaccumulation is an active process, whereby the biomass transports the metal ions into the cells where the metal is then sequestered. The disadvantage of this process is that the concentration of the metal may reach a level that is toxic to the 
TABLE1

Performance characteristics of some heavy metal removal and recovery technologies (Eccles, 1999)

\begin{tabular}{|c|c|c|c|c|c|}
\hline \multirow[t]{2}{*}{ Technology } & \multicolumn{5}{|c|}{ Performance characteristics } \\
\hline & $\mathrm{pH}$ change & $\begin{array}{l}\text { Metal } \\
\text { selectivity }\end{array}$ & $\begin{array}{l}\text { Influence of } \\
\text { suspended } \\
\text { solids }\end{array}$ & $\begin{array}{l}\text { Tolerance to } \\
\text { organic } \\
\text { molecules }\end{array}$ & $\begin{array}{l}\text { Metal } \\
\text { working } \\
\text { level (mg/l) }\end{array}$ \\
\hline Adsorption (e.g. GAC*) & Limited tolerance & Moderate & Fouled & Can be poisoned & $<10$ \\
\hline Electrochemical & Tolerant & Moderate & $\begin{array}{l}\text { Can be engineered } \\
\text { to tolerate }\end{array}$ & $\begin{array}{l}\text { Can be } \\
\text { accommodated }\end{array}$ & $>10$ \\
\hline Ion exchange & Limited tolerance & $\begin{array}{l}\text { Some selectivity } \\
\text { (e.g.chelatingresins) }\end{array}$ & Fouled & Can be poisoned & $<100$ \\
\hline Precipitation as hydroxide & Tolerant & Non-selective & Tolerant & Tolerant & $>10$ \\
\hline Solvent extraction & $\begin{array}{l}\text { Some tolerant } \\
\text { systems }\end{array}$ & $\begin{array}{l}\text { Metal-selective } \\
\text { extractants } \\
\text { available }\end{array}$ & Fouled & Intolerant & $>100$ \\
\hline
\end{tabular}

organism, and kill it. Biosorption is a passive process in which the metal adsorbs to functional groups on the outer surface of the biomass. This process can occur on both living and dead biomass and thus, the only limiting factor is the availability of binding sites onto which the metal can adsorb (Volesky, 1990).

Membrane processes involving the removal of heavy metals from solution are mainly limited to those that require a membrane as a pretreatment filtration device linked to a second removal mechanism. An example of this is a combination of membrane technology and solvent extraction suggested by Kentish and Stevens (2001) in which metal is removed from industrial wastewater. In this example, the membrane is placed between the waste stream and the solvent stream and mass transfer of the selected chemical species occurs across the membrane into the solvent.

Chemical precipitation is still the simplest and cheapest means of removing metals from solution (Sheikholeslami and Bright, 2002). The increase in $\mathrm{pH}$ caused by the precipitant results in the immobilisation of the metal ions in insoluble forms, either as a metal hydroxide or a metal sulphide (Eccles, 1999). Sodium hydroxide introduces the least amount of inert material to the sludge, but this becomes expensive in the long-term, as large volumes of effluent and metal-laden sludge are produced and must be treated daily (Van Hille et al., 1999). For example, the hydroxide precipitation of $100 \mathrm{mg} /$ $\ell$ copper(II) produces as much as $1000 \mathrm{mg} / \ell$ sludge (Eccles, 1999). Traditionally hydroxide precipitants such as lime and caustic soda are favoured over their sulphide counterparts, due to the much higher cost of chemically produced hydrogen sulphide $\left(\mathrm{H}_{2} \mathrm{~S}\right)$ and the hazards associated with its manipulation (Cowan, 1998).

\section{Sulphide precipitation of metals}

Despite the disadvantages, there are a number of countering advantages to using sulphide as a precipitant. One is the production of lower sludge volumes compared to hydroxide precipitation (Kaksonen et al., 2003). This has huge financial impacts on waste management strategies for all metal producers, as smaller volumes result in lower disposal or reclamation costs. Sulphide also readily forms metal sulphides, the solubilities of which are very low in comparison to the corresponding hydroxides (Kaksonen et al., 2003; Hao, 2000) and carbonates (Bayoumy et al., 1999), hence even moderate sulphide outputs can effectively precipitate metals, reducing levels to well below those permitted for environmental discharge (White et al., 1997). Additionally, valuable metals can be recovered from the sulphide sludges (Kaksonen et al., 2003).

The cost of chemically produced $\mathrm{H}_{2} \mathrm{~S}$ is no longer an obstacle to the use of sulphide precipitation. The defining line between chemical and biological wastewater treatment becomes blurred as more and more research is focusing on the use of biological sources of sulphide gas and the most commonly studied source of the gas are a group of organisms known as sulphate-reducing prokaryotes (SRP). The SRP include a range of anaerobic, mesophilic bacteria the sulphate-reducing bacteria (SRB) (White et al., 1997). Sulphatereducing prokaryotes can be broadly defined as a mixed group of nutritionally and morphologically diverse, strictly anaerobic eubacteria and archaebacteria capable of utilising oxidised sulphur compounds, including sulphate, as electron acceptors for the oxidation of organic compounds such as organic acids, fatty acids, and alcohols, which act as carbon and electron donor sources (Brüser et al., 2000). A significant aspect of SRP metabolism is the production of $\mathrm{H}_{2} \mathrm{~S}$, a strong reducing agent, capable of inhibiting the growth of bothanaerobic and aerobic micro-organisms (O’Flaherty and Colleran, 2000). Hydrogen sulphide production is via a process known as dissimilatory sulphate reduction (Fig. 3), in which the sulphate ion is utilized as an oxidant for the degradation of organic matter, i.e. as an electron acceptor for the oxidation of carbon substrates.

$$
2 \mathrm{LACTATE}+3 \mathrm{SO}_{4}^{2-} \rightarrow 6 \mathrm{HCO}_{3}^{-}+3 \mathrm{HS}^{-}+\mathrm{H}^{+}
$$

Almost all of the sulphate reduced is released as sulphide and may be converted to $\mathrm{HS}^{-}$or $\mathrm{H}_{2} \mathrm{~S}$ (Brüser et al., 2000).

A second process, assimilatory sulphate reduction, is responsible for the availability of sulphur for incorporation into amino 
acids (Fig. 3). Plants, animals and bacteria, without exception, require sulphur for the synthesis of proteins. The highest oxidation state of sulphur, the sulphate ion $\left(\mathrm{SO}_{4}^{2-}\right)$ must first be reduced to sulphide $\left(\mathrm{S}^{2-}\right)$ before it can be incorporated into amino acids. The assimilatory reduction of sulphate is common in prokaryotes, plants and fungi, while the dissimilatory pathway is restricted to prokaryotes (Brüser et al., 2000). The SRP perform both dissimilatory and assimilatory sulphate reduction and generate sulphide $\left(\mathrm{H}_{2} \mathrm{~S} / \mathrm{HS}^{-}\right)$, with dissimilatory products far exceeding assimilatory reduction products.

Currently, 18 genera of dissimilatory SRP are known, and have been placed into two broad groups based on preferences for carbon and energy sources. Group I contains genera such as Desulfovibrio, Desulfomonas, Desulfotomaculum and Desulfobulbus. This group can use lactate, pyruvate, ethanol or certain fatty acids as carbon and energy sources. The second group includes genera such as Desulfobacter, Desulfococcus, Desulfosarcina and Desulfonema that specialise in the oxidation of fatty acids, particularly acetate (Madigan et al., 2003). In conjunction with a large consortium of other micro-organisms (mainly methanogenic and acetogenic bacteria), SRP are responsible for the complete degradation of organic matter under anaerobic conditions (Fig. 4)

The habitat of SRP is restricted to anaerobic areas containing high levels of inorganic sulphate and a suitable carbon source, such as waterlogged soils and muds, sewage pipes, drains and pits, stagnant ponds and the rumens of ruminant animals. The anaerobic regions of marine and estuarine sediments are characterised by high sulphate contents and so are primary growth sites for SRP. Carbon sources in this habitat are provided by heterotrophic activities in the water column overlying the sediment, or from a direct organic input, such as sewage. Sulphate-reducing bacterial activity has also been noted in freshwater sediments (Gibson, 1990).

Sulphate reducers have been used successfully to treat electroplating rinse effluent (Song et al., 1998) and copperladen wastewater (Jalali and Baldwin, 2000). Van Hille et al. (1999) reported on the application of SRP in the treatment of acid mine drainage (AMD), where the SRP were able to significantly reduce sulphate levels and produce enough alkalinity to raise the $\mathrm{pH}$ to acceptable levels. This method of AMD treatment

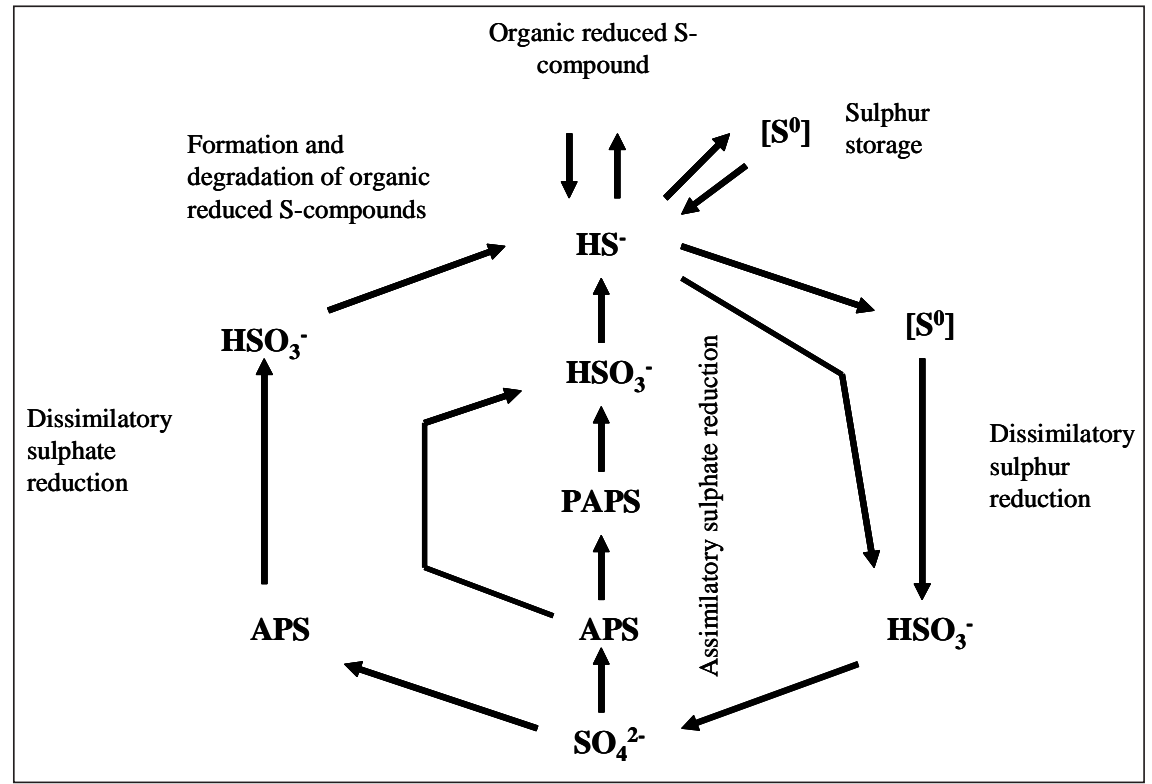

Figure 3

The biological sulphur cycle ([S $\mathrm{S}^{0}$ : compound in which 0 oxidation state occurs, such as polythionates, polysulfanes, etc. APS: adenosine-5'-phosphosulphate. PAPS: phosphoadenosine-5'-phosphosulphate) (Brüser et al., 2000)

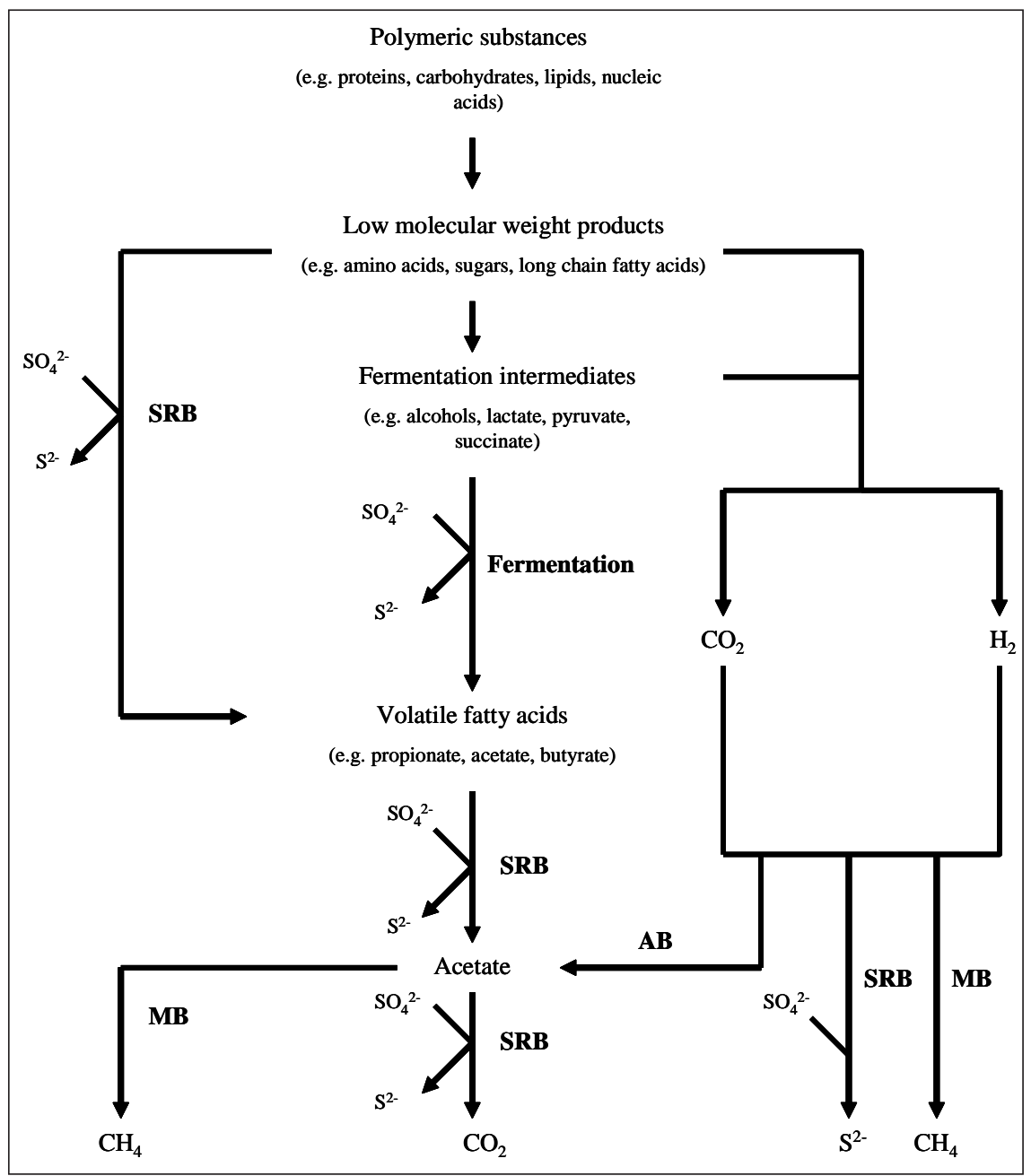

Figure 4

Pathway of the anaerobic degradation of organic matter, showing potential interactions of sulphate-reducing bacteria. (SRB = sulphate-reducing bacteria; $\mathrm{MB}=$ methanogenic bacteria; $\mathrm{AB}=$ acetogenic bacteria) (Adapted from Lens et al., 2000) 
was also used to treat water at a disused mine in France, where the selective precipitation of metals for recovery was also investigated (Foucher et al., 2001), and further demonstrated by Kaksonen et al. in 2003. The immobilisation of a number of other toxic metal ions in sulphide ores such as uranium, thorium and radium has also been shown to be efficient (Groudev et al., 2001).

A number of large-scale processes utilise biological sulphate reduction and metal precipitation as significant components of metal removal strategies. Metal sulphide precipitation is especially significant in the operation of both constructed and natural wetland systems (White et al., 1997).

Studies conducted by Machemer and Wildeman (1992) showed that sulphide precipitation eventually becomes the dominant process for metal removal in constructed wetlands. Machemer et al. (1993) reported the same phenomenon during studies conducted at the Big Five Tunnel in Idaho Springs, Colorado.

The possible application of SRP-generated $\mathrm{H}_{2} \mathrm{~S}$ in the precipitation of metal ions has been studied in a number of intensive process reactor designs. These include upflow anaerobic sludge blanket reactors (UASB) (Weijma et al., 2003; Yamaguchi et al., 2001), anaerobic contact processes, anaerobic filters (Dvorak et al., 1992; Elliott et al., 1998), hybrid reactors (Nedwell and Reynolds, 1996), fluidised-bed reactors (FBR) (Kaksonen et al., 2003) and extractive membrane bioreactors (EMBR) (Chuichulcherm et al., 2001).

\section{Membrane processes}

A membrane is best defined as a material through which one type of substance can pass more readily than others (Stephenson et al., 2000). This implies that it acts as a semi-permeable barrier to separate one bulk solution phase from another while allowing the convection or diffusive transport of a small molecule present in solution in either direction across the barrier, and preventing the simultaneous transport of another larger molecule (Kentish and Stevens, 2001). When used in the treatment of wastewater, the membrane may act in one (or more) of three ways: the membrane may act to reject pollutants and allow purified water through; it may act to extract pollutants from water (Livingston, 1994) or it may act as a vehicle for the bubble-less transfer of gas (e.g. oxygen) into wastewater to augment microbial degradation (Casey et al., 1999). Membrane materials vary widely in both physical structure and chemical composition. However, the most fundamentally impor-

TABLE2

Dense and porous membranes for water treatment (Stephenson et al., 2000)

\begin{tabular}{|c|c|}
\hline Dense & Porous \\
\hline $\begin{array}{c}\text { Reverse osmosis } \\
\text { solubility and diffusion rates of } \\
\text { water (solvent) and dissolved } \\
\text { species (solutes) in water. }\end{array}$ & $\begin{array}{c}\text { Ultrafiltration } \\
\text { Separation of both large, } \\
\text { dissolved solute molecules } \\
\text { and suspended colloidal } \\
\text { particles by size exclusion. }\end{array}$ \\
\hline $\begin{array}{c}\text { Electrodialysis } \\
\text { size, charge and charge density } \\
\text { of solute ions, using ion } \\
\text { exchangemembranes. }\end{array}$ & $\begin{array}{c}\text { Microfiltration } \\
\text { Separation of suspended } \\
\text { solids from water by } \\
\text { size exclusion. }\end{array}$ \\
\hline
\end{tabular}

\section{Nanofiltration}

Separation through combination of charge rejection, solubility-diffusion and sieving.

\begin{tabular}{|c|c|c|c|c|c|}
\hline \multicolumn{6}{|c|}{$\begin{array}{l}\text { TABLE3 } \\
\text { Advantages and disadvantages of current membrane configurations (Stephenson et al., 2000) }\end{array}$} \\
\hline Configuration & $\begin{array}{l}\text { Area: } \\
\text { Volume } \\
\left(\mathrm{m}^{2}: \mathrm{m}^{3}\right)\end{array}$ & $\begin{array}{l}\text { Turbulence } \\
\text { promotion }\end{array}$ & Advantages & Disadvantages & Applications \\
\hline Pleated cartridge & $800-1000$ & Very poor & $\begin{array}{c}\text { Robust } \\
\text { construction } \\
\text { Compact design } \\
\text { Low cost }\end{array}$ & $\begin{array}{l}\text { Easily fouled } \\
\text { Cannot be cleaned }\end{array}$ & Dead end MF \\
\hline Plate-and-frame & $400-600$ & Fair & $\begin{array}{l}\text { Can be dismantled } \\
\text { for cleaning }\end{array}$ & $\begin{array}{c}\text { Complicated design } \\
\text { Cannot be backflushed } \\
\text { High cost }\end{array}$ & ED, UF, RO \\
\hline Spiral-wound & $800-1000$ & Poor & $\begin{array}{l}\text { Low energy cost } \\
\text { Robust and compact } \\
\text { Low cost }\end{array}$ & $\begin{array}{l}\text { Not easily cleaned - } \\
\text { cannot be backflushed }\end{array}$ & $\mathrm{RO}, \mathrm{UF}$ \\
\hline Tubular & $20-30$ & Very good & $\begin{array}{l}\text { Easily mechanically } \\
\text { cleaned } \\
\text { Tolerant of high TSS* }\end{array}$ & $\begin{array}{c}\text { High capital and } \\
\text { membrane replacement } \\
\text { cost }\end{array}$ & $\begin{array}{l}\text { Cross-flow filtration, } \\
\text { high TSS waters }\end{array}$ \\
\hline Hollow fibre & $5000-40000$ & Very poor & $\begin{array}{l}\text { Can be backflushed } \\
\text { Compact design } \\
\text { Tolerant of high colloidal } \\
\text { levels }\end{array}$ & $\begin{array}{l}\text { Sensitive to pressure } \\
\text { shocks }\end{array}$ & MF, RO \\
\hline
\end{tabular}


tant property, which provides the basis for membrane categorisation, is that of the mechanism by which the separation is achieved. This characteristic separates membranes into one of two broad groups, either dense or porous.

When considering dense membrane separations, physico-chemical interactions between the permeating components and the membrane material play a major role in the process (Table 2). For example, reverse osmosis (RO) is able to achieve the highest selectivity due to the ability to separate ionic species from molecular species. Porous membranes achieve separation mechanically and so are closer to conventional filtration processes. Generally, porous membranes are used in membrane bioreactors, as they act to retain the suspended solids material, i.e. biomass, within the bioreactor whilst producing a clarified effluent. A second, more practical categorisation of membranes is according to the material composition, which is generally either organic (polymeric) or inorganic (ceramic or metallic).

The shape of a membrane, (i.e. the geometry) plays a crucial role in the overall process performance. A number of characteristics have been identified which ensure that the process is designed to optimize membrane performance (Stephenson et al., 2000). These are: a high membrane surface area to volume ratio; turbulence to promote mass transfer through the membrane; low energy expenditure per unit product water volume, ease of cleaning and modularisation. However, when considering these criteria, a degree of compromise must be expected, as some of the characteristics are mutually exclusive. For example, energy expenditure increases with increasing turbulence. Five membrane configurations are currently employed, all of which have various practical benefits and limitations (Table 3). These configurations are based on either a planar or cylindrical geometry.

Membrane separation technology has been used to remove metal ions from a range of solutions via microfiltration (ZakrzewskaTrznadel, 2003) nanofiltration (Van der Bruggen and Vandecasteele, 2003; Qdais and Moussa, 2004) and reverse osmosis (Wong et al., 2002; Qdais and Moussa, 2004). Zakrzewska-Trznadel (2003), investigated the application of inorganic membranes for processing of metallic radioactive wastes. Experiments with treatment of synthetic and real radioactive waters with nanofiltration and ultrafiltration ceramic membranes enhanced by chemical complexation showed that metallic radioisotopes could be removed from wastewaters. Later, Qdais and Moussa (2004) found that nanofiltration was a successful technique for the removal $\mathrm{Cu}^{2+}$ and $\mathrm{Cd}^{2+}$ from wastewater. Qdais and Moussa (2004) were able to reduce the heavy metal concentration in synthetic wastewater to environmentally acceptable levels and concluded that the reuse of industrial wastewater containing heavy metals after treatment by $\mathrm{RO}$ and NF is feasible. However, the use of membrane separation in conjunction with biological metal removal from solution is an area of even greater interest and again the distinction between physicochemical and biological wastewater treatment becomes indistinct with the increasing application of membrane bioreactors.

\section{Membrane bioreactors}

The coupling of a membrane to a bioreactor has attracted a large amount of attention in recent years, both academically and commercially. This is due to the advantages this process offers over conventional biological wastewater treatment systems (Van Houten et al., 2001; Visvanathan et al., 2000). Membrane bioreactors (MBRs) have emerged as viable alternative wastewater treatment processes in areas where space (for settling ponds, etc.) and water resources are limited and are gaining popularity as alternatives when treating industrial wastewaters with high total dissolved solids, where settling and clarification are often a problem (Enegess et al., 2003; Van der Roest et al., 2001).

\section{Solid-liquid separations}

Biomass separation membrane bioreactors are the most common type of MBR. These MBRs can be considered a combination of a suspended growth reactor and a membrane filtration device. The membrane unit can be configured either external to (Fig. 5A) or immersed in the bioreactor (Fig. 5B) (Fane and Chang, 2002). In the set-up described in Fig. 5A, the membrane is independent of the bioreactor and feed is circulated from the bioreactor to the membrane unit where permeate is discharged and retentate returned to the feed tank. The immersed system differs in that there is no recirculation loop and the separation occurs within the bioreactor (Stephenson et al., 2000).

Typically, the immersed system involves a substantial increase in the membrane area per unit volume, relative to the external system. It is also capable of operating at much lower transmembrane pressures (TMP) and at a lower liquid cross-flow velocity. The implication of these characteristics is that operating an internal membrane system requires a lower cost and energy input (Enegess et al., 2003; Gander et al., 2000).

The benefits of these solid-separation membrane bioreactors are superior to most (if not all) non-membrane-based separation techniques. The permeate from the membrane is typically free from solids and macro-colloidal material and it is possible to obtain complete retention of all suspended matter including bacteria and viruses, making the water safe for discharge into the receiving environment (Stephenson et al., 2000). De Korte et al. (2001) state that, along with the complete removal of bacteria and viruses, MBRs should significantly reduce heavy metal and organic micropollutant (such as pesticides and polyaromatic hydrocarbon (PAH)) loads. A smaller footprint is attainable with an MBR system, as the single filtration step takes the place of a conventional multi-stage process involving primary settlement, secondary biological treatment and a possible polishing step (Gander et al., 2000). For example, Cicek et al. in 1999 compared the performance of an MBR to an activated sludge system (Table 4). Both systems were fed the same synthetic sewage. They showed that the flocs in the MBR, as well as being

\begin{tabular}{|c|c|c|}
\hline \multicolumn{3}{|c|}{$\begin{array}{c}\text { TABLE4 } \\
\text { Performance comparison between activated sludge } \\
\text { and an MBR fed an identical synthetic sewage } \\
\text { (Cicek et al., 1999) }\end{array}$} \\
\hline Performance characteristic & $\begin{array}{l}\text { Activated } \\
\text { sludge }\end{array}$ & MBR \\
\hline Sludge age(days) & 20 & 30 \\
\hline $\mathrm{COD}^{1}$ removal (\%) & 94.5 & 99 \\
\hline DOC $^{2}$ removal (\%) & 92.7 & 96.9 \\
\hline TSS removal (\%) & 60.9 & 99.9 \\
\hline Ammoniacal $\mathrm{N}^{3}$ removal (\%) & 98.9 & 99.2 \\
\hline Total $\mathrm{P}^{4}$ removal (\%) & 88.5 & 96.9 \\
\hline Sludge production (kgVSS $5 / \mathrm{kgCOD} \mathrm{d})$ & 0.22 & 0.27 \\
\hline Mean floc sizes $(\mu \mathrm{m})$ & 20 & 3.5 \\
\hline $\begin{array}{ll}{ }^{1} \text { Chemical oxygen demand } & { }^{2} \text { Dissolv } \\
& { }^{4} \text { Phosph } \\
{ }^{3} \text { Nitrogen } & \end{array}$ & \multicolumn{2}{|c|}{$\begin{array}{l}{ }^{2} \text { Dissolved organic carbon } \\
{ }^{4} \text { Phosphate }\end{array}$} \\
\hline
\end{tabular}




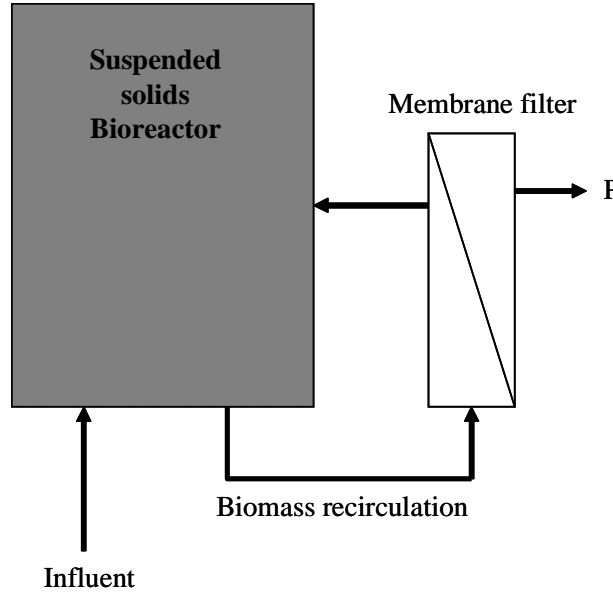

$\mathbf{A}$

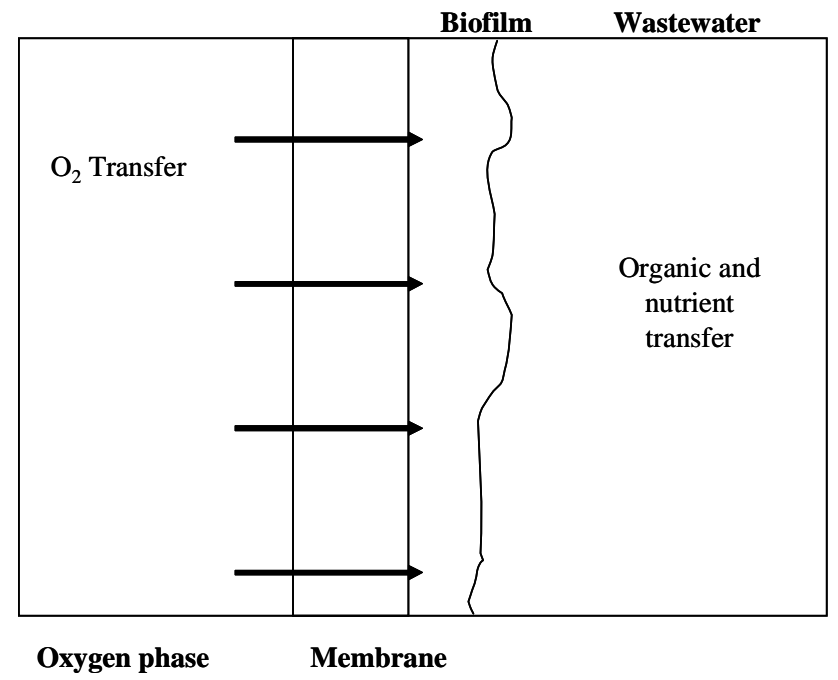

Figure 6

Schematic diagram of the MABR process. Oxygen is transported through the pores of the hydrophobic membrane into the biofilm. Organics and nutrients are transferred from the wastewater to the biofilm (Stephenson et al., 2000)

smaller, were more active and displayed greater species diversity. The enzyme activity in the MBR was also higher, but that was attributed to washout in the activated sludge system.

The results in Table 4 illustrate the reason for the major area of research interested in applying MBRs in the treatment of municipal wastewater. A large number of these systems have been developed to a commercial scale.

Since the 1980s MBR technology has been successfully applied to a range of industrial wastes, including oily wastes (Knoblock et al., 1994), food wastes (Mallon et al., 1999), tannery effluents (Yamamoto and Win, 1991) and landfill leachates (Mishra et al., 1996). In Tunisia, wastewaters from the detergent and cosmetic industries are being targeted for MBR treatment. The Tunisian standard level for discharge of wastewater containing surfactants is $5 \mathrm{mg} / \ell$. However, the industries are producing up to $100000 \mathrm{t}$ of wastewater a year containing more than $1 \mathrm{~g} / \ell$ of surfactants. An MBR system has been shown to eliminate between 0.065 to $0.15 \mathrm{~g} / \ell \cdot \mathrm{h}$ of surfactant with a hydraulic retention time of $5 \mathrm{~h}$ (Dhouib et al., 2003).
Figure 5

Configurations of solid-liquid MBRs:

A. Sidestream and

B. submerged (Stephenson et al., 2000)

\section{Membrane aeration bioreactors}

A basic requirement for the aerobic degradation of organic material is oxygen, which is required to support the life and growth of the microbes performing the degradation. It is therefore imperative that these systems receive sufficient oxygen as, without it, a rapid deterioration in the quality of effluent will occur (Brindle et al., 1998). The rate of oxygen mass transfer can be greatly improved by using high purity oxygen rather than atmospheric air, but these oxygenation devices require a lot of power in order to efficiently mix the gas into solution and hence cannot be used in conjunction with biofilm processes where the reactor should remain static (Stephenson et al., 2000; Brindle et al., 1998).

The membrane aeration bioreactor (MABR) concept was developed in response to the need for increased oxygen mass transfer into wastewaters in cases where the oxygen requirements for degradation of the pollutant were too high for conventional aeration processes. It is also applicable when the possibility exists that the bubbling of air would result in either the stripping of volatile organic carbons or of foaming of industrial wastewaters (Pankhania et al., 1999). The membrane itself can play a dual role in the reactor, namely as a means for supplying oxygen and by providing a substrate for supporting biofilm formation

Figure 6 is a schematic diagram outlining the principle of the MABR. A membrane (dense gas permeable, hydrophobic porous or composite) is used to transfer oxygen to the bacteria present in the bioreactor without forming bubbles. The membrane also acts as a support for biofilm development. Wastewater flows over the outer surface of the biofilm and counter-diffusion of oxygen and pollutant occurs. The oxygen is utilised in the degradation of pollutants in the biofilm.

Membrane aeration bioreactors have been use to treat a wide variety of wastewater types and have been shown to be particularly effective in treating high oxygen demanding wastewaters (Yamagiwa et al., 1994), biodegradation of volatile organic compounds (Kniebusch et al., 1990), combined nitrification (Timberlake et al., 1988), denitrification and/or organic carbon degradation in a single biofilm (Hirasa et al., 1991).

\section{Extractive membrane bioreactors}

Most work focused on the implementation of extractive membrane bioreactors (EMBRs) has been with regard to chemical industry wastewaters and the toxic organic compounds present therein (Livingston, 1994). Biological degradation of these compounds is well understood and appears to be the ideal solution for the reduction 


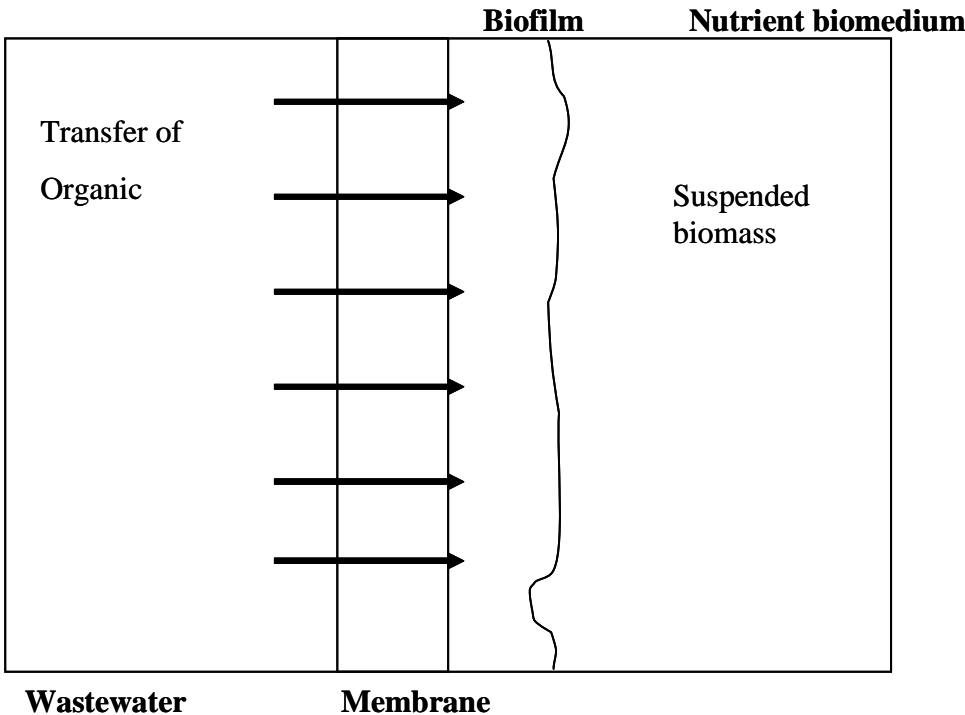

of these emissions into the environment. However, a number of factors complicate this. A major factor is the complex nature of the final effluent as it leaves the process; this includes the number and variety of organic compounds and the composition of the inorganic fraction (salts, acids, bases, metal salts) (Livingston et al., 1998). Others include the presence of recalcitrant pollutants that simply pass through the treatment system and the possible stripping of volatile organic compounds into the atmosphere (Freitas dos Santos et al., 1995; Brookes and Livingston, 1994).

A seemingly obvious solution to these problems would be to bioaugment the existing microbial cultures in the wastewater treatment plant with specialised cultures capable of degrading toxic, recalcitrant pollutants as they pass through the plant.

However, studies on specialised cultures that would be required have concentrated on degradation in 'ideal' conditions, where the only pollutant present is that which requires degrading, and where the growth medium is carefully controlled to supply maximal nutrient requirements in order for the culture to survive and degrade efficiently. This has translated to difficulties arising when the culture is faced with 'real' industrial conditions (Livingston, 1994). Thus, the problem faced can be summarised as provision of conditions suitable for biodegradation of toxic organic pollutants discharged as components of complex wastewater streams that may inhibit the growth and efficacy of the specialised culture. The problems described have led to researchers developing a membrane bioreactor capable of solving this problem, the EMBR.

The principle of an EMBR is illustrated in Fig. 7. An industrial wastewater containing the organic compound to be degraded is passed over one surface of a selectively permeable membrane, while a microbial culture is maintained in an aqueous biomedium at the other surface. The $\mathrm{pH}$ and ionic strength of the wastewater have no influence on the makeup of the biomedium as the membrane is effectively impermeable to any inorganic or charged species in the wastewater. Thus the biomedium conditions can be controlled to provide optimal growth conditions for the microbial culture in spite of the biologically hostile makeup of the wastewater (Livingston et al., 1998).

Studies involving synthetic wastewater streams at laboratory scale have yielded highly successful results. Freitas dos Santos and Livingston (1994) reported a >99\% removal of 1, 2-dichloroethane from an initial concentration of $1600 \mathrm{mg} / \ell$. 2, 4-Dichlorophenoxyacetic acid, a component of commercial herbicides, has also been successfully degraded at laboratory scale using a suitably acclimated microbial culture(Buenrostro-Zagal etal., 2000). Jorge and Livingston (2000) found that the two most commonly used solvents in the chemical and pharmaceutical industries, toluene and dichloromethane, were possibly being degraded by a commensal microbial culture.

When the EMBR is used with industrial wastewaters the results are equally encouraging. Wastewater from a 3-chloronitrobenzenemanufacture plant was successfully remediated with removal efficiencies of greater than $99 \%$ achieved at residence times of approximately 30min (Brookes and Livingston, 1994). Brookes and Livingston (1995) operated a laboratory-scale reactor continuously for 5 months and consistently removed aniline, 4-chloroaniline, 2,3dichloroaniline and 3,4-dichloroaniline at efficiencies greater than $99 \%$.

Other successes include the removal and degradation of compounds such as monochlorobenzene, where 98 to $99 \%$ of the pollutant was destroyed at a flow rate of $50 \mathrm{l} / \mathrm{h}$ (Livingston et al., 1998), 1, 2-dichloroethane (94.5\% removal) with negligible airstripping (Freitas dos Santos and Livingston, 1995) and various other chemical and pharmaceutical waste streams with similar results.A number of variations on the EMBR configuration have also been tested. Lui et al. (2001) showed the efficiency of the EMBR in a liquid-liquid extraction configuration by degrading chlorophenolic compounds such as 2, 4,6-trichlorophenol, 2,4dichloroaniline and pentachlorophenol to levels lower than 100 $\mu \mathrm{g} / \ell$. The degradation of a waste gas stream containing $1,2-$ dichloroethane was investigated by Freitas dos Santos et al. (1995) and resulted in removal of $91 \%$ of the pollutant.

\section{Recovery of metal ions using membrane bioreactors}

Metal-laden wastewaters usually contain compounds that may be toxic or inhibit the growth of micro-organisms and they are often saline or exhibit extremes of $\mathrm{pH}$. This description fits that of a wastewater suitable for treatment via EMBR. Conventional technologies for the removal of metals from such wastewaters include precipitation, ion exchange and absorption.

Biological production of $\mathrm{H}_{2} \mathrm{~S}$ is already considered a conventional method of precipitating metals from wastewaters. In this method the SRB is grown in direct contact with the wastewater and the resulting $\mathrm{H}_{2} \mathrm{~S}$ causes metal precipitation. These metal sulphides are insoluble and can thus be easily separated. However, this application is limited by the inhibition of microbial activity due to the biologically hostile characteristics of the wastewater. 


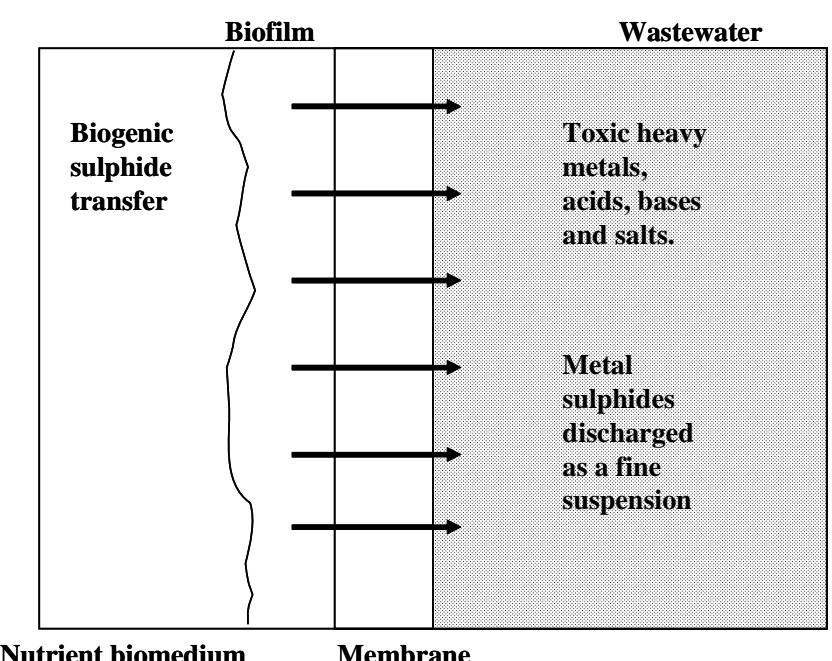

Nutrient biomedium Membrane

Figure 8

A schematic diagram of the EMBR-SRB treatment system. A silicone-based membrane separates the two aqueous phases, while allowing $\mathrm{H}_{2} \mathrm{~S}$ to permeate from the biomedium phase into the wastewater and so precipitate the metal. Charged species in the wastewater cannot permeate the membrane, making it possible to pass highly inhibitory wastewaters through the tubes without inhibiting the SRB (Chuichulcherm et al., 2001).

An EMBR system can be used to solve these limitations by preventing the direct contact between the SRB and the wastewater. Figure 8 illustrates the principle of the EMBR-SRB (extractive membrane bioreactor: sulphate-reducing bacterial) system.

Chuichulcherm et al. (2001) developed the EMBR-sulphide linked concept and tested it for the removal of $\mathrm{Zn}$ from synthetic wastewaters. Zinc was chosen as the wastewater metal as it is considered safe and a good representative of metals, and has a higher solubility product with sulphide than other metals.

From the results obtained, it was concluded that a fast reaction occurs between the $\mathrm{H}_{2} \mathrm{~S}$ and the $\mathrm{Zn}$ ions on the wastewater side of the membrane. This reaction was believed to enhance the transfer of $\mathrm{H}_{2} \mathrm{~S}$ across the membrane by forming a concentration gradient. Moreover, when the $\mathrm{pH}$ of the biomedium was decreased, it was found that the amount of undissociated $\mathrm{H}_{2} \mathrm{~S}$ increased, further increasing the strength of the concentration gradient.

The rate of mass transfer of $\mathrm{H}_{2} \mathrm{~S}$ was studied and was found to be dependent on the membrane thickness. The authors also found that a thin layer of $\mathrm{Zn}$ sulphide was deposited on the wastewater side of the membrane and became the dominant resistance to $\mathrm{H}_{2} \mathrm{~S}$ mass transfer. It was suggested that this problem could be overcome by changing the hydrodynamic conditions of the waste stream, either by increasing the waste flow rate and/or using pulsed flow, which may decrease the accumulation on the membrane surface.

They concluded by stating that the EMBR-SRB system can be used successfully for the treatment of metal-containing wastewaters. In this case, over $90 \%$ (w/w) of $\mathrm{Zn}$ ion was removed from the model waste, which initially contained $250 \mathrm{mg} / \ell \mathrm{Zn}$.

\section{Acknowledgements}

Financial support from the National Research Foundation of South Africa is hereby acknowledged. Financial support from the Department of Labour of South Africa is also hereby acknowledged. Opinions expressed and conclusions reached are those of the authors and are not to be attributed to the Department of Labour.

\section{References}

ADAMS MD (2003) On-site gold refining of cyanide liquors by solvent extraction. Miner. Eng. 16 369-373.

ALVA-ARGÁEZ A, KOKOSSIS AC and SMITH R (1998) Wastewater minimisation of industrial systems using an integrated approach. Comput. Chem. Eng. 22 5741-5744.

BAETENS D (2002) Water pinch analysis; minimisation of water and wastewater in the process industry. In: Water Recycling and Resource Recovery in Industry: Analysis, Technologies and Implementation. IWA Publishing, London.

BAYOUMY ME, BEWTRA JK, ALI HI and BISWAS N (1999) Removal of heavy metals and COD by SRB in UAFF reactor. J. Environ. Eng. June 532-539.

BRINDLE K, STEPHENSON T and SEMMENS MJ (1998) Nitrification and oxygen utilisation in a membrane aeration bioreactor. J. Membr. Sci. 144 197-209.

BROOKES PR and LIVINGSTON AG (1994) Biological detoxification of a 3-chloronitrobenzene manufacture wastewater in an extractive membrane bioreactor. Water Res. 28 1347-1354.

BROOKES PR and LIVINGSTON AG (1995) Aqueous-aqueous extraction of organic pollutants through tubular silicone rubber membranes. J. Membr. Sci. 104 119-137

BROUCKAERT CJ, SCHNIEDER J, MANSFIELD M and BUCKLEY CA (2002) Water pinch analysis as a transparent tool for the coregulation of industrial processes. Proc. WISA Biennial Conf. 2002. Durban, South Africa.

BRÜSER T, LENS PNL and TRÜPER HG (2000) The biological sulfur cycle. In: Lens PNL and Hulshoff Pol L (eds.) Environmental Technologies to Treat Sulfur Pollution. IWA Publishing, London 393-414.

BUENROSTRO-ZAGAL JF, RAMÍREZ-OLIVA A, CAFFARELMÉNDEZ S, SCHETTINO-BERMÚDEZ B and POGGI-VARALDO HM (2000) Treatment of a 2,4-dichlorophenoxyacetic acid (2,4-D) contaminated wastewater in a membrane bioreactor. Water Sci. Technol. 42 (5-6) 185-192.

CASEY E, GLENNON B and HAMER G (1999) Review of membrane aerated biofilm reactors. Res. Conserv. Recyc. 27 203-215.

CHUICHULCHERM S, NAGPAL S, PEEVA L and LIVINGSTON A (2001) Treatment of metal-containing wastewaters with a novel extractive membrane reactor using sulfate-reducing bacteria. J. Chem. Technol. Biotechnol. 76 61-68.

CICEK N, FRANCO JP, SUIDAN MT, URBAIN V and MANEM J (1999) Characterisation and comparison of a membrane bioreactor and a conventional activated-sludge system in the treatment of wastewater containing high-molecular-weight compounds. Water Environ. Res. 71 64-70.

CORTINA JL, MEINHARDT E, ROIJALS O and MARTÍ V (1998) Modification and preparation of polymeric adsorbents for precious-metal extraction in hydrometallurgical processes. React. Funct. Polym. 36 149-165.

COWAN JAC (1998) The Development of Management Strategies and Recovery Systems for Heavy Metal Wastes. Water Research Commission Report No. 589/1/98. Water Research Commission, Pretoria, South Africa.

DE KORTE K, MULDER J-W, SCHELLEN A and SCHYNS P (2001) MBR will be the wastewater treatment plant of the future, vision from the water authorities. $\mathrm{H}_{2} \mathrm{O}$ October 22-25.

DEPARTMENT OF ENVIRONMENTAL AFFAIRS AND TOURISM (2001) Environmental Potential Atlas. http://www.environment.gov.za. (accessed $2^{\text {nd }}$ September 2003).

DHOUIB A, HAMAD N, HASSAÏRI I and SAYADI S (2003) Degradation of anionic surfactants by Citrobacter braakii. Process Biochem. 38 1245-1250.

DIELS L, VAN ROY S, MERGEAY M, DOYEN W, TAGHAVI S and LEYSON R (1993) Immobilization of bacteria in composite membranes and development of tubular membrane reactors for heavy metal recuperation. $3^{\text {rd }}$ Int. Conf. on Effective Membrane Processes - New Perspectives. Mechanical Engineering Publications Limited. UK. 
DVORAK DH, HEDIN RS, EDENBORN HM and McINTIRE PE (1992) Treatment of metal-contaminated water using bacterial sulfate reduction: results from pilot-scale reactors. Biotechnol. Bioeng. 40 609-616.

ECCLES H (1999) Treatment of metal-contaminated wastes: Why select a biological process? TIBTech 17 462-465.

ELLIOTT P, RAGUSA S and CATCHESIDE D (1998) Growth of sulfate-reducing bacteria under acidic conditions in an upflow anaerobic bioreactor as a treatment system for acid mine drainage. Water Res. 32 (12) 3724-3730.

ENEGESS D, TOGNA AP and SUTTON PM (2003) Membrane separation applications to biosystems for wastewater treatment. Filtr. Separat. 40 (1) 14-17.

FANE AG and CHANG S (2002) Membrane bioreactors: design and operational options. Filtr. Separat. 39 (5) 26-29.

FOUCHER S, BATTAGLIA-BRUNET F, IGNATIADIS I And MORIN D (2001) Treatment by sulphate-reducing bacteria of Chessy acidmine drainage and metals recovery. Chem. Eng. Soc. 56 16391645.

FREITAS DOS SANTOS LM and LIVINGSTON AG (1994) Extraction and biodegradation of a toxic volatile organic compound (1, 2-dichloroethane) from wastewater in a membrane bioreactor. Appl. Microbiol. Biotechnol. 42 421-431.

FREITAS DOS SANTOS LM and LIVINGSTON AG (1995) Novel membrane bioreactor for detoxification of VOC wastewaters: biodegradation of 1, 2-dichloroethane. Water Res. 29 (1) 179-194.

FREITAS DOS SANTOS LM, HÖMMERICH U and LIVINGSTON AG (1995) Dichloroethane removal from gas streams by an extractive membrane bioreactor. Biotechnol. Prog. 11 194-201.

GANDER M, JEFFERSON B and JUDD S (2000) Aerobic MBRs for domestic wastewater treatment: A review with cost considerations. Sep. Purif. Technol. 18 119-130.

GENÇ Ö, SOYSAL L, BAYRAMOLU G, ARICA MY and BEKTA S (2003) Procion Green H-4G immobilized poly (hydroxyethylmethacrylate/chitosan) composite membranes for heavy metal removal. J. Hazard. Mater. 97 (1-3) 111-125.

GHOLIVAND MB and NOZARI N (2000) Extraction and spectrophotometric determination of trace amounts of $\mathrm{Pd}(\mathrm{II})$ with 2,2'dithiodianiline. Talanta 52 (6) 1055-1060.

GIANADDA P, BROUCKAERT CJ, SAYER R and BUCKLEY CA (2002) The application of pinch analysis to water, reagent and effluent management in a chlor-alkali facility. Water Sci. Technol. 46 (9) 21-28.

GIBSON GR (1990) A review. Physiology and ecology of the sulphatereducing bacteria. J. Appl. Bacteriol. 69 769-797.

GROUDEV SN, GEORGIEV PS, SPASOVA II and KOMNITSAS K (2001) Bioremediation of a soil contaminated with radioactive elements. Hydrometall. 59 311-318.

HAO OJ (2000) Metal effects on sulfur cycle bacteria and metal removal by sulfate reducing bacteria. In: Lens PNL and Hulshoff Pol L (eds.) Environmental Technologies to Treat Sulfur Pollution. IWA Publishing, London. 393-414.

HIRASA O, ICHIJO H and YAMAUCHI A (1991) Preparation of new support for immobilisation of activated sludge. J. Ferment. Bioeng. 71 376-378.

HOLTZHAUSEN L (2002) The war for water. Fighting the battle for the last drop. WASE 22 (2) 26-29.

JALALI K and BALDWIN SA (2000) The role of sulphate reducing bacteria in copper removal from aqueous sulphate solutions. Water Res. 34 (3) 797-806.

JOOSTE S (2000) A model to estimate the total ecological risk in the management of water resources subject to multiple stressors. Water SA 26 (2) 159-166.

JORGE RMF and LIVINGSTON AG (2000) Biological treatment of an alternating source of organic compounds in a single tube extractive membrane bioreactor. J. Chem. Technol. Biotechnol. 75 11741182.

JUANG R-S and SHIAU R-C (2000) Metal removal from aqueous solutions using chitosan-enhanced membrane filtration. J. Membr. Sci. 165 (2) 159-167.
KAKSONEN A.H, RIEKKOLA-VANHANEN M-L and PUHAKKA JA (2003) Optimization of metal sulphide precipitation in fluidized-bed treatment of acidic wastewater. Water Res. 37 255-266.

KENTISH SE and STEVENS GW (2001) Innovations in separations technology for the recycling and re-use of liquid waste streams. Chem. Eng. J. 84 149-159.

KNIEBUSCH MM, WILDERER PA and BEHLING RD (1990) Immobilisation of cells on gas permeable membranes. In: Physiology of Immobilised Cells. Elsevier Science, Amsterdam, The Netherlands. 149-160.

KNOBLOCK MD, SUTTON PM, MISHRA PN, GUPTA K and JANSON A (1994) Membrane biological reactor system for treatment of oily wastewaters. Water Environ. Res. 66 133-139.

LEE SH, JUNG CH, LEE MY and YANG J-W (1998) Removal of heavy metals from aqueous solution by apple residues. Process Biochem. 33 (2) 205-211.

LENS PNL, OMIL F, LEMA JM and HULSHOFF POL LW (2000) Biological treatment of organic sulfate-rich wastewaters. In: Lens PNL and Hulshoff Pol LW (eds.) Environmental Technologies to Treat Sulfur Pollution. IWA Publishing, London. 153-173.

LIVINGSTON AG (1994) Extractive membrane bioreactors: A new process technology for detoxifying chemical industry wastewater. J. Chem. Technol. Biotechnol. 60 117-124.

LIVINGSTONE AG, ARCANGELI J-P, BOAM AT, ZHANG S, MARANGON M and FREITAS DOS SANTOS LM (1998) Extractive membrane bioreactors for detoxification of chemical industry wastes: Process development. J. Membr. Sci. 151 29-44.

LUI W, HOWELL JA, ARNOT TC and SCOTT JA (2001) Extractionmembrane bio-reactor for treating priority pollutants in the presence of inorganics. Membrane Tech. 133 4-7.

MACHEMER SD and WILDEMAN TR (1992) Adsorption compared with sulfide precipitation as metal removal processes from acid mine drainage in a constructed wetland. J. Contam. Hydrol. 9 (12) $115-131$

MACHEMER SD, REYNOLDS JS, LAUDON LS and WILDEMAN TR (1993) Balance of S in a constructed wetland built to treat acid mine drainage, Idaho Springs, Colorado, USA. Appl. Geochem. 8 (6) 587-603.

MADIGAN MT, MARTINKO JM and PARKER J (2003) Brock: Biology of Microorganisms (10 ${ }^{\text {th }}$ edn.). Prentice-Hall Inc. New Jersey. 671-673.

MALLON D, STEEN F, BRINDLE K and JUDD S (1999) Performance on a real industrial effluent using a Zenogem MBR. MBR2 - Proc. $2^{\text {nd }}$ Int. Meeting on Membrane Bioreactors for Wastewater Treatment. Cranfield University, Cranfield, UK.

MISHRA PN, SUTTON PM and MOURATO D (1996) Industrial wastewater biotreatment optimisation through membrane applications. Proc. $89^{\text {th }}$ Meeting of the Air and Waste Management Association. Nashville.

MORRISON G, FATOKI OS, ZINN E and JACOBSSON D (2001) Sustainable development indicators for urban water systems: A case study of King William's Town, South Africa, and the applied indicators. Water SA 27 (2) 219-232.

NATIONAL WATER ACT (Act 36 of 1998). Republic of South Africa Government Gazette 398 (19182).

NEDWELL DB and REYNOLDS PJ (1996) Treatment of landfill leachate by methanogenic and sulfate-reducing digestion. Water Res. 30 (1) 21-28.

O'FLAHERTY V and COLLERAN E (2000) Sulfur problems in anaerobic digestion. In: Lens PNL and Hulshoff Pol L (eds.) Environmental Technologies to Treat Sulfur Pollution. IWA Publishing, London. 467-489.

PANKHANIA M, BRINDLE K and STEPHENSON T (1999) Membrane aeration bioreactors for wastewater treatment: completely mixed and plug-flow operation. Chem. Eng. J. 73 131-136.

QDAIS HA and MOUSSA H (2004) Removal of heavy metals from wastewater by membrane processes: A comparative study. Desalination 164 (2) 105-110.

SCHUTTE CF and PRETORIUS WA (1997) Water demand and population growth. Water SA 23 (2). Cited in: Thompson B (1998) 
Comment on "Water demand and population growth". Water SA 24 (3) 265-268.

SHEIKHOLESLAMI R and BRIGHT J (2002) Silica and metals removal by pre-treatment to prevent fouling of reverse osmosis membranes. Desalination 143 255-267.

SONG Y-C, PIAK B-C, SHIN H-S and LA S-J (1998) Influence of electron donor and toxic materials on the activity of sulphatereducing bacteria for the treatment of electroplating wastewater. Water Sci. Technol. 38 (4-5) 187-194.

STEPHENSON T, BRINDLE K, JUDD S and JEFFERSON B (2000) Membrane Bioreactors for Wastewater Treatment. IWA Publishing, London, UK.

SULKA GD and JASKUBA M (2003) Study of the kinetics of silver ions cementation onto copper from sulphuric acid solution. Hydrometall. 70 (1-3) 185-196.

SWALAHA FM, DATADIN S and CHOONAWALA BB (2002) Assessment and Application of Imported Biomass for The Bioremediation of Heavy Metal Effluents. Water Research Commission Report No. 1083/1/02. Water Research Commission, Pretoria, South Africa.

TIMBERLAKE DL, STRAND SE and WILLIAMSON KJ (1988) Combined aerobic heterotrophic oxidation, nitrification and denitrification in a permeable support biofilm. Water Res. 22 15131517.

VAN DER BRUGGEN B and VANDECASTEELE C (2003) Removal of pollutants from surface water and groundwater by nanofiltration: overview of possible applications in the drinking water industry. Environ. Pollut. 122 (3) 435-445.

VAN DER ROEST H, LEENEN J, HOFSTRA M, BOEVE J and VAN DER VLIST J (2001) The Dutch contribution to the MBR development in perspective. $\mathrm{H}_{2} \mathrm{O}$ October 7-9.

VAN HILLE RP, BOSHOFF GA, ROSE PR and DUNCAN JR (1999) A continuous process for the biological treatment of heavy metal contaminate acid mine water. Res. Conserv. Recyc. 27 157-167.

VAN HOUTEN R, EVENBLIJ H and KEIJMEL M (2001) Membrane bioreactors hit the big time - ten years of research in the Netherlands. $\mathrm{H}_{2} \mathrm{O}$ October 26-29.
VISVANATHAN C, BEN AIM R and PARAMESHWARAN K (2000) Membrane separation bioreactors for wastewater treatment. Crit. Rev. Environ. Sci. Technol. 30 (1) 1-48.

VOLESKY B (1990) Biosorption and biosorbents In: Volesky B (ed.) Biosorption of Heavy Metals. CRC Press, Boca Rotan, Florida, USA. 3-5.

WEBSTER E (Ed) (2001) Water reuse to solve SA water shortage. Water Sewage and Effluent 21 (1)12.

WEIJMA J, CHI TM, HULSHOFF POL LW, STAMS AJM and LETTINGA G (2003) The effect of sulphate on methanol conversion in mesophilic upflow anaerobic sludge bed reactors Process Biochem. 38 (9) 1259-1266.

WHITE C, SAYER JA and GADD GM (1997) Microbial solubilisation and immobilisation of toxic metals: Key biogeochemical processes for treatment of contamination. FEMS Microbiol. Rev. 20 503516.

WONG F-S, QIN J-J, WAI MN, LIM AL and ADIGA M (2002) A pilot study on a membrane process for the treatment and recycling of spent final rinse water from electroless plating. Sep. Purif. Technol. 29 (1) 41-51.

WRIGHT KA and XU Y (2000) A water balance approach to the sustainable management of groundwater in South Africa. Water SA 26 (2) $167-170$.

YAMAGIWA K and OHKAWA A (1994) Simultaneous organic carbon removal and nitrification by biofilm formed on oxygen enrichment membrane. J. Chem. Eng. Japan 27 638-643.

YAMAGUCHI T, YAMAZAKI S, UEMURA S, TSENG I-C, OHASHI A and HARADA H (2001) Microbial-ecological significance of sulfide precipitation within anaerobic granular sludge revealed by micro-electrodes study. Water Res. 35 (14) 4311-3417.

YAMAMOTO K and WIN KM (1991) Tannery wastewater treatment using a sequencing batch membrane reactor. Water Sci. Technol. 23 (7-9) 1639-1648.

ZAKRZEWSKA-TRZNADEL G (2003) Radioactive solutions treatment by hybrid complexation-UF/NF process. J. Membr. Sci. 225 (1-2) 25-39.

ZHELEV TK and BHAW N (2000) Combined water-oxygen pinch analysis for better wastewater treatment management. Waste Manage. 20 665-670. 